\title{
Sustainable Crop Production In Tidal Lowlands: A Research Agenda
}

\author{
Khairul Fahmi Purba ${ }^{1}$, Muhammad Yazid ${ }^{1 *}$ \\ ${ }^{1}$ Master Program in Agribusiness, Faculty of Agriculture, Sriwijaya University, Indonesia \\ *Corresponding Author's e-mail address: yazid_ppmal@yahoo.co
}

Article history

\begin{tabular}{lllr}
\hline Received & Received from reviced & Accepted & Available online \\
07 December 2018 & 07 January 2019 & 08 january 2019 & 11 January 2019 \\
\hline
\end{tabular}

\begin{abstract}
Tidal lowlands bear enormous potential including crop production. However, tidal lowlands also have numbers of ecosystem functions that prevent them from exploitative uses. Therefore, tidal lowland utilization for crop production should consider measures to achieve sustainable development goals (SDGs) in one hand. In the other hand, SDGs should also ensure the sustainable use of tidal lowlands. This paper aims to review the sustainability of crop production in tidal lowland to support the achievement of SDGs, which are eliminating hunger, achieving food security with good nutrition, and improving sustainable agriculture. These goals need to be achieved in 2030 by ensuring sustainable crop production systems, applying tough agricultural practices, increasing production and productivity, and at the same time maintaining tidal lowland ecosystems. Therefore, this paper will review three major aspects as follows: (1) productive means of crop cultivation, (2) effective control of agricultural waste and pollutant, and (3) efficient use of agricultural inputs. This review is expected to yield sustainable measures of crop production in tidal lowlands to contribute to the achievement of sustainable development goals (SDGs).

Keywords : Crop production, sustainable development, tidal lowlands
\end{abstract}

Abstrak (Indonesian):Lahan pasang surut memiliki potensi besar termasuk produksi tanaman pangan. Namun, lahan pasang surut juga memiliki sejumlah fungsi ekosistem yang mencegahnya dari penggunaan eksploitatif. Oleh karena itu, pemanfaatan lahan pasang surut untuk produksi tanaman pangan harus mempertimbangkan langkahlangkah untuk mencapai tujuan pembangunan berkelanjutan (SDGs). Di sisi lain, SDGs juga harus memastikan pemanfaatan berkelanjutan lahan pasang surut. Makalah ini bertujuan untuk mengkaji keberlanjutan produksi tanaman pangan di lahan pasang surut untuk mendukung pencapaian SDGs, yaitu menghapuskan kelaparan, mencapai ketahanan pangan dengan gizi yang baik, dan meningkatkan pertanian berkelanjutan. Tujuan ini perlu dicapai pada tahun 2030 dengan memastikan sistem produksi tanaman berkelanjutan, menerapkan praktik pertanian yang tangguh, meningkatkan produksi dan produktivitas, dan pada saat yang sama menjaga ekosistem. Oleh karena itu, makalah ini akan meninjau tiga aspek utama sebagai berikut: (1) sistem budidaya tanaman pangan yang produktif, (2) pengendalian efektif atas limbah dan bahan pencemar pertanian, dan (3) penggunaan input pertanian yang efisien. Tinjauan ini diharapkan dapat menghasilkan ukuran produksi tanaman pangan yang berkelanjutan di pasang surut untuk berkontribusi pada pencapaian tujuan pembangunan berkelanjutan (SDGs).

Katakunci: Produksi tanaman pangan, pembangunan berkelanjutan, lahan pasang surut

\section{Introduction}

Half of the world's population makes rice a staple food. Rice farming is also a source of livelihood for majority of Asian people [1], [2]. Indonesia is one of the countries that has a high level of rice consumption and rural communities still depend on rice farming as their main source of income. Indonesia's population occupies the fourth largest position in the world. The population of Indonesia in the next 40 years will continue to grow with a growth rate of around $2.5 \%$ per year, so that the need for food will also increase [3]. Government is obliged to guarantee the availability, affordability and fulfillment of food consumption for the people of Indonesia (Government Regulation Number 18/ 2012 concerning Food). The government is responsible to provide sufficient food for all Indonesian people. Besides, the rampant land conversion and land carrying capacity are no longer able to sustain crop production. In order to provide sufficient food, developing farming in tidal lowlands has been considered a solution [4], [5].

Large area of tidal lowlands in Sumatra and Borneo is potential to encourage agricultural development, support food security and support agribusiness enterprises, especially in food sector [6]. Central Bureau of Statistics in 2016 reported that one of the largest reclaimed tidal lowlands is located in South Sumatera (266,674 Ha). Majority of this area is situated in Banyuasin Regency. Banyuasin Regency has been declared as agricultural region and is expected to be a food barn. The tidal land area in Banyuasin Regency is 184,700 Ha (Central Bureau of 
Statistics of Banyuasin Regency, 2015). Tidal lowlands are located along the Eastern Coast of Banyuasin which include several sub-districts such as Muara Padang, Makarti Jaya, Muara Telang, Banyuasin II, Pulau Rimau, Air Saleh, Muara Sugihan, Talang Kelapa, Betung and Tungkal Ilir. Tidal lowlands as agricultural resource which is expected to sustain crop production needs to be maintained in order to fulfill food needs for the next generation. Tidal lowlands can be maintained through proper utilization of agricultural inputs, sufficient maintenance of infrastructures, and effective control on farmland from conversion [7].

Sustainable Development Goals (SDGs) are documents that contain global goals and targets for the year 2016 to 2030. Maintaining the sustainability of tidal lowlands as agricultural area is in accordance to the achievement of SDGs. One of the goals of SDGs is to improve sustainable agriculture and responsible production. The target in the SDGs document is to ensure a sustainable crop production system and implement resilient agricultural practices that increase production and productivity and help safeguard the environment and ecosystem in 2030. [8], [9].

Among problems that exist in tidal lowland, especially regarding environmental issues, the question arises regarding the sustainability of crop production in tidal lowland. There is a lack of appropriate measures in determining crop production sustainability. Several indicators of sustainability are found in the Sustainable Development Goals (SDGs), but they can not be used to measure the sustainability of crop production since the indicators are incomplete in terms of calculations and not in accordance with the specific location. Therefore, a study of the determination of measure and assessment of tidal lowland crop production is needed. The proposed question is "What researches are necessary to yield appropriate assessment and measures of sustainability of crop production in tidal lowlands?"

The objective of this paper is to examine the sustainability of crop production in tidal lowlands with regards to the achievement of Sustainable Development Goals (SDGs) through review of relevant literature. This paper is expected to yield measures of sustainable crop production in tidal lowlands to contribute to the achievement of sustainable development goals (SDGs).

\section{Material and Methods}

This paper was written through review of relevant literature in crop production development in tidal lowlands from both theoretical and methodological perspectives. The literature reviewed included journals, sustainable development goals (SDGs) documents, reports, etc.

\section{Results and Discussion}

Tidal lowland is located in a flat area near the sea which is dependent on tidal movements. Water in tidal lowlands is normally fresh water from the river which is due to the influence of tidal and low tide of the sea water, is used to irrigate the land through irrigation and drainage canals. Tidal lowland is generally located around main river that is influenced by tidal and low tides [10]. Tidal lowland is located in a flat area, so that overflowing and periodic inundation become its typical characteristics [11]. In addition to land typology, the type of overflow has a very important meaning in determining the suitability of the area for farming. Based on its hydrotopography tidal lowland can be classified into four categories, namely:

1. Type A is an area that can be overflowed by either high or low tide.

2. Type B is an area that can only be overflowed by high tides.

3. Type $\mathrm{C}$ is an area that is not flooded by tide, but the depth of groundwater level is less than $50 \mathrm{~cm}$ below the ground.

4. Type $\mathrm{D}$ is an area that is not affected by tide at all and the depth of groundwater surface is more than 50 $\mathrm{cm}$ below the ground.

Types A and B are often referred to as direct tides, while types $\mathrm{C}$ and $\mathrm{D}$ are referred to as indirect tides [11]. Tidal lowlands have the prospect to be developed into agricultural land to support crop production. Therefore, its sustainable use must be conserved for future generations.

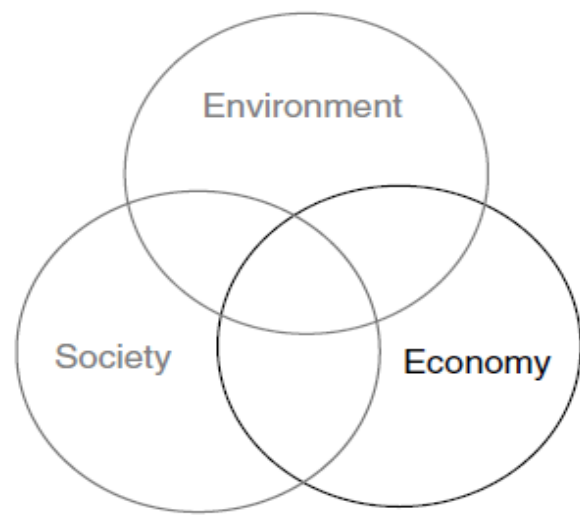

Figure 1. Common three-ring sector view of sustainable development

Sustainable development is a development that meets today's needs without compromising the ability of future generations to meet their needs. There are several components in sustainable development such as economic growth, social inclusion, and environmental protection. Sustainable development can be achieved if the three components integrate well each other [8]. SDGs provide 17 goals. However, with regard to crop production in tidal lowlands this paper focuses in goal 
\#2 and goal \#12 of the SDGs. So far economic factors have been prioritized while environmental factors are often ignored, even though human beings as social factors will never be separated from environmental factors [12]. The concept of sustainable development is proposed to cope with this situation. The following figure is depicted the relationship between the three components of sustainable development.

Based on the definitions, maintaining the sustainability of tidal lowlands means the need for food is sufficient for current as well as for future generations. This concept is important to overcome the threats to sustainable crop production in tidal lowlands such as excessive use of seed in direct seedling, the use of chemical fertilizers, herbicides, pesticides, and inefficient use of water due to improper water management.

Based on the concept of sustainable development, several research agenda for assessing and determining appropriate measures of sustainability of crop production in tidal lowlands is proposed in accordance to achieving Sustainable Developement Goals (SDGs). The agenda accommodates the economic and social measures to reflect the productive means of crop cultivation and the efficient use of agricultural inputs. It also includes environmental measures to reflect effective control of agricultural waste and pollutant (Figure 2).

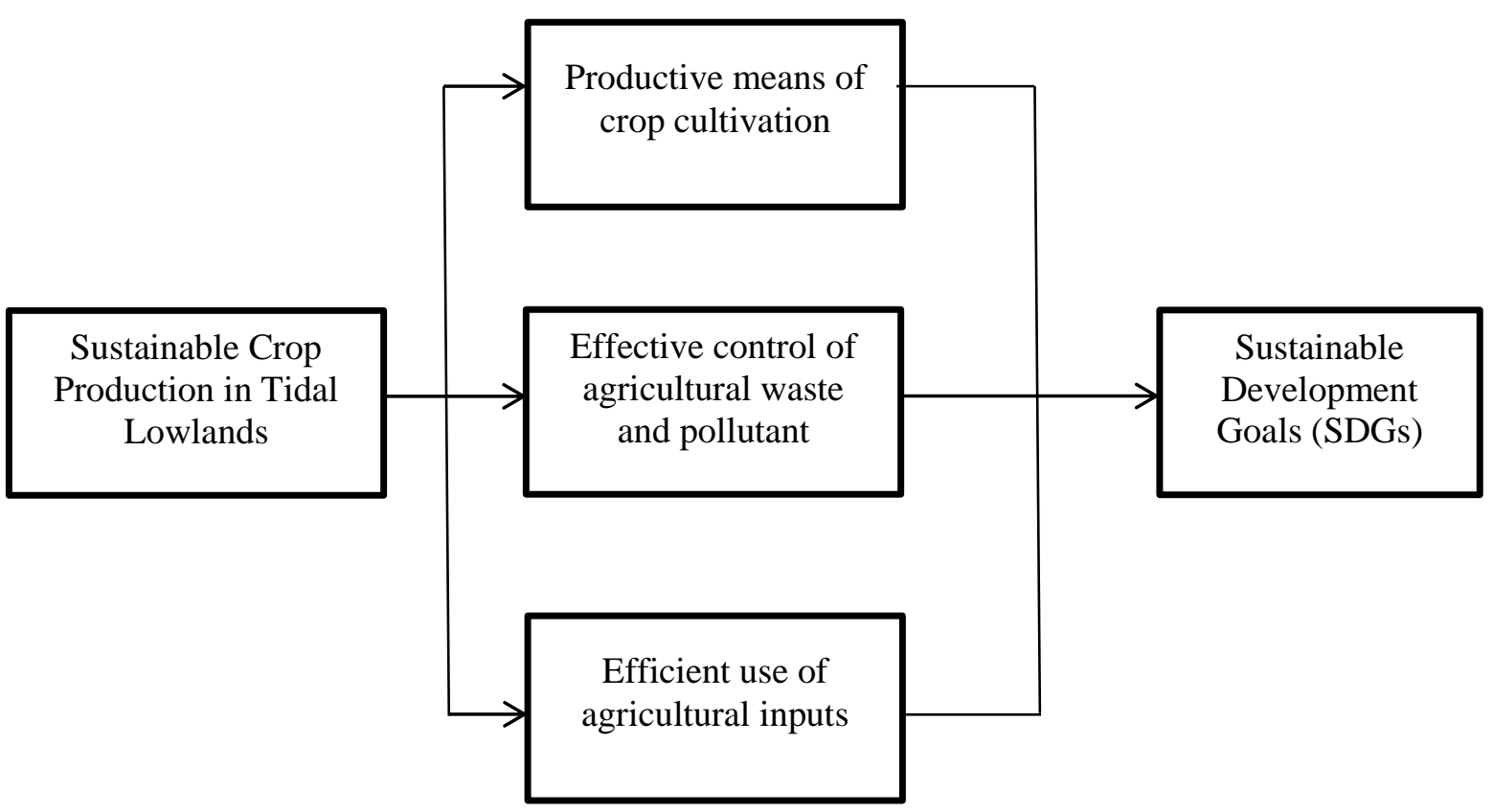

Figure 2. The Agenda for Research in Sustainable Crop Production

\subsection{The productive means of crop cultivation}

Water management is a key for productive crop cultivation in tidal lowlands [13]. Crop cultivation in tidal lowlands is highly dependence to water management and network functions. Currently, water management in tidal lowland is not in accordance with the crop needs such that crop production is not optimal [14].

Water management requires cooperation among farmers (water users) within a water management unit. In this case, establishing water users association (WUA) is a must since water management requires consensus and mutual actions regarding operation and maintenance of water management system. With well functioning WUA, crop water needs can be well fulfilled and better crop production can be achieved [13].

Another problem in tidal lowland farming is the presence of pyrite which causes the soil acidity to increase. Pyrite is a substance found only in peat soil in tidal lowland areas. This substance is formed when the land is inundated by sea water that enters during the dry season. In inundated conditions, pyrite is not harmful to plants. However, when exposed to air (oxidized), the pyrite forms into iron and sulfuric acid which can poison plants [15]. To solve the problem, water management to maintain ground water level become the most effective solution [16], [17].

Other problem regarding productive means in crop production in tidal lowlands is the use of local rice variety. Farmers still use local variety even though the productivity is considered low. Some superior varieties such as Inpara and IR42 are used by few farmers [18]. These varieties have been proved to give higher productivity (5 - 5.8 tons/ha) compared to local variety (4.5 tons/ha).

Rice farming in certain areas in tidal lowlands was done only in wet season through "slash-plant-leave" practice [18]. This practice makes tidal lowlands remain abandoned. When farmers finish planting rice, 
they leave the land bared the rest of the months until the next planting season. This practice is considered not sustainable. As explained in SDGs, sustainable crop production system requires good agricultural practice to increase production and maintain the ecosystem and the environment in 2030.

Based on the above explanation, it is necessary to research on the topic of productive means of crop cultivation to examine what productive means that can maintain the sustainability of crop production in tidal lowlands. This research is expected to serve as measures for sustainable cultivation and guidelines for good agriculture practice in tidal lowland crop production and maintenance of tidal ecosystem.

\subsection{Effective control of agricultural waste and pollutant}

Tidal lowland agriculture has the potential to cause environmental problems since it produces waste and pollutants that are harmful to tidal lowland ecosystem. Furthermore, it may reduce biodiversity and responsible for the extinction of various sources of biodiversity and the increase of $\mathrm{CO}_{2}$ emissions [18].

Some of the chemical compounds that potentially damage the environment in tidal lowlands are $\mathrm{Fe}^{2+}$, $\mathrm{Al}^{3+}$ dan $\mathrm{SO}_{4}{ }^{2-}$. To solve this problem water management is required. Proper water management will wash the chemical compounds [14], [16]. Current practice in tidal lowland agriculture is the high use of chemicals such as fertilizers, pesticides and herbicides [19]. Increasing use of chemical and pesticide is coincided with low crop productivity which in turn affect negatively the perception of farmers in maintaining tidal lowland agro-ecosystem.

The use of chemicals raises the externality and the costs required to remove the externality is higher than the external costs of chemical use in tidal lowlands [20]. Therefore, the use of chemicals in tidal lowland crop production should be reduced. Instead, the use of organic materials to improve tidal lowlands conditions should be promoted. Waste from rice farming in tidal lowlands is abundant and is currently burnt. Its utilization as organic materials will reduce the negative impact of both chemicals use and emission of waste burning.

There are several targets of SDGs goal \#12, among those is sustainable waste management in order to improve soil conditions. Other targets listed on this goal are substantially reducing waste production through prevention and reduction-recycling-reuse. Rice waste such as husk and straw can be used as organic materials to achieve sustainable production pattern as the target of SDGs. Rice straw and husk can be used for fertilizer and feed to promote rice-vegetableslivestock integration in tidal lowland agriculture. The integrated farm is able to improve sulphate acid in soil after 4-5 years [20].
Based on the above description, a research investigating the problems of agricultural waste and pollutants in tidal lowlands and finding an effective solution to these problems is deemed necessary. Through such research, it can be expected that agricultural waste and pollutants can be controlled effectively to safeguard the environment and ecosystem as a measure of sustainability in tidal lowland agriculture.

\subsection{Efficient Use of Agricultural Input}

In crop production, land, seeds, fertilizers, and labor are considered as inputs. The use of agricultural inputs in tidal lowlands is relatively low [18]. One of the input that is used in less efficient way is land. This is indicated by low planting intensity in tidal lowlands. Majority of farm land is used one time in a year (Crop index 100). In addition, farmers practice direct seedling through broadcasting method. Consequently, the use of seed is much higher than transplanting method, so is the cost. This current practice does not support the achievement of goal \#12 of SDGs, which is the production activity must efficient and responsible on the environment.

Food crop farming in tidal lowlands is less profitable compared to estate crops. Diversification through multiple food crops or combining food crops and estate crops, could be a solution. Diversification provides more opportunities to increase farmers' income. Surveys showed that farmers living in tidal lowland ecosystems have low income. Therefore, the development of tidal lowland agriculture must consider high market value crops while keeping the potential of swamps as food barns of South Sumatra Province.

Farmers in tidal lowland cultivate rice once a year even though tidal lowlands can be cultivated twice or more. This means that farmers do not utilize agricultural land efficiently. Efficient use of agricultural land as potential natural resource is in accordance with goal \#12 of the SDGs to ensure a sustainable production and consumption pattern to achieve sustainable management and resource utilization by 2030 . This mismatch will lead to unsustainable development.

Economic theory introduces efficiency as a measure of viable agribusiness. Although there has been limited researches showing the efficiency of agricultural inputs utilization in tidal lowland agriculture, the efficient use of agricultural inputs should be adopted to increase crop production and reduce costs. Therefore, it is deemed necessary to investigate the efficient use of inputs on tidal lowlands agriculture. This research is expected to clearly explain the optimum use of agricultural inputs while maintain the low level of waste and pollutants released and agricultural green house gases emitted to the atmosphere. 


\section{Conclusion}

In order to achieve sustainable crop production in tidal lowlands according to Goals \#2 and \#12, the research agenda of sustainable crop production in tidal lowland should include:

1. Investigation on measures of productive means of crop cultivation in tidal lowlands to yield with indicators that contribute to the achievement of goal \#2 of The SDGs to ensure sustainable agriculture practices.

2. Seeking an effective control of agricultural waste and pollution in crop production in tidal lowlands to achieve goal \#12 of The SDGs to ensure responsible production system and reduce chemical use in crop production.

3. Estimate the efficient use of agricultural inputs in crop production in tidal lowlands to achieve goal \#12 of the SDGs to ensure sustainable management and resource utilization and efficiency.

\section{Acknowledgement}

The authors wish to thank The Master Program in Agribusiness, Faculty of Agriculture, Sriwijaya University and The Ministry of Research, Technology and Higher Education of The Republic of Indonesia through PMDSU Scholarship Batch III.

\section{References}

[1] R. Roy, N. W. Chan, and R. Rainis, "Rice farming sustainability assessment in Bangladesh," Sustain. Sci., vol. 9, no. 1, pp. 3144, 2014.

[2] R. Roy, N. W. Chan, and S. Xenarios, "Sustainability of rice production systems: an empirical evaluation to improve policy," Environ. Dev. Sustain., vol. 18, no. 1, pp. 257278, 2016.

[3] F. Sjarkowi, Tujuh puluh tujuh siasat membangun kedaulatan pangan nasional penguat peutuhan NKRI. Palembang: CV. Baldad, 2014.

[4] T. Suwarno, Alihamsyah, and I. G. Ismail, "Optimasi pemanfaatan lahan rawa pasang surut dengan penerapan sistem usaha tani terpadu. Prosiding Seminar Nasional Penelitian dan Pengembangan Pertanian di Lahan Rawa," in Seminar Nasional Penelitian dan Pengembangan Pertanian di Lahan Rawa, 2000, pp. 176-186.

[5] D. Nazemi, A. Hariani, and Nurita, "Optimalisasi pemanfaatan lahan rawa pasang surut melalui pengelolaan lahan dan komoditas," J. Agrovigor, vol. 5, no. 1, pp. 5257, 2012.

[6] T. Alihamsyah, "Optimalisasi pendayagunaan lahan rawa pasang surut," in Seminar Nasional Optimalisasi Pendayagunaan Sumberdaya
Lahan, 2002, p. 29.

[7] V. N. Hoang and M. Alauddin, "InputOrientated Data Envelopment Analysis Framework for Measuring and Decomposing Economic, Environmental and Ecological Efficiency: An Application to OECD Agriculture," Environ. Resour. Econ., vol. 51, no. 3, pp. 431-452, 2012.

[8] UN, "Goal 2: End hunger, achieve food security and improved nutrition and promote sustainable agriculture - SDG Indicators," Millenn. Dev. Goals beyond 2015, no. March, p. 2, 2015.

[9] BAPPENAS, Ringkasan metadata Tujuan pembangunan berkelanjutan (TPB)/ Indikator Sustainable development goals (SDGs) Indonesia. 2017.

[10] Puslitbangtanak, "Arahan Lahan Sawah Utama dan Sekunder Nasional di P. Jawa, P. Bali, dan P. Lombok," The Author(s), 2003.

[11] I. Ar-riza and Alkasuma, "Pertanian Lahan Rawa Pasang Surut dan Strategi Pengembangannya dalam Era Otonomi Daerah," J. Sumberd. Lahan, vol. 2, no. 2, pp. 95-104, 2008.

[12] B. Giddings, B. Hopwood, and G. O. Brien, "Environment, Economy And Society: Fitting Them Together Into Sustainable Development," Sustain. Dev., vol. 10, pp. 187-196, 2002.

[13] H. Suprianto et al., "Landandwater Management Of Tidal Lowlands: Experiences In Telang And Saleh, South Sumatra," Irrig. Drain., vol. 59, pp. 317-335, 2010.

[14] M. Yazid, "Chemical Use In Tidal Lowland Agriculture," in FCC 2010 International Conference on Food Safety and Security Under Changing Climate, 2010.

[15] A. I. Widjaja, N. S. Ratmini, and I. W. Swastika, Pengelolaan Tanah dan Air di Lahan Pasang Surut. Jakarta: Badan Penelitian dan Pengembangan Pertanian, 1997.

[16] M. S. Imanudin and E. Armanto, "Effect of Water Management Improvement on Soil Nutrient Content, Iron and Aluminum Solubility at Tidal Low Land Area," APCBEE Procedia, vol. 4, no. 62711580460, pp. 253258, 2012.

[17] L. Hutahaean, E. E. Ananto, and B. Raharjo, "Pengembangan Teknologi Pertanian Lahan Rawa Pasang Surut Dalam Mendukung Peningkatan Produksi Pangan: Kasus di Sumatera Selatan," Memperkuat Kemamp. Swasembada Pangan, pp. 89-108, 2015.

[18] E. E. Ananto, Zakiah, and E. Pasandaran, "Potensi Lahan Rawa Pasang Surut Dalam Mendukung Peningkatan Produksi Pangan," Jakarta: Kementerian Pertanian Indonesia, 2011, pp. 153-168. 
[19] Warsito, R. H. Susanto, E. Saleh, and Novia, "Ammonium and Nitrate of Soil in Relation to Water Table Fluctuation at the Tidal Rice Fields," Sriwij. J. Environ., vol. 3, no. 2, pp. 61-67, 2018.
[20] A. Susilawati, D. Nursyamsi, and M. Syakir, "Optimalisasi Penggunaan Lahan Rawa Pasang Surut Mendukung Swsembada Pangan Nasional," J. Sumberd. Lahan, vol. 10, no. 1, pp. 51-64, 2016. 